\title{
REDISTRIBUTION OF DNA LOOP DOMAINS IN HUMAN LYMPHOCYTES UNDER BLAST TRANSFORMATION WITH INTERLEUKIN 2
}

\author{
K. S. AFANASIEVA, M. I. CHOPEI, A. V. LOZOVIK, \\ S. R. RUSHKOVSKY, A. V. SIVOLOB \\ Educational and Scientific Centre Institute of Biology and Medicine, \\ Taras Shevchenko National University of Kyiv, Ukraine; \\ e-mail: aphon@ukr.net
}

\begin{abstract}
At higher order levels chromatin fibers in interphase nuclei are organized into loop domains. Gene regulatory elements (promoters and enhancers) are often located near the sites of loop attachments. Therefore, loop domains play a key role in regulation of cell transcriptional activity. We investigated the kinetics of DNA loop exit during single cell gel electrophoresis (the comet assay) of nucleoids obtained from two cell types that differ in their synthetic activity - human lymphocytes and lymphoblasts. Lymphocyte activation and transformation into lymphoblasts (blast transformation) was performed with interleukin 2. The results obtained suggest that a rearrangement of the loops occurs after lymphocyte activation. After blast transformation we observed an increase of the amount of loop domains on the surface of nucleoids against a decrease of the inner loop fraction. Therefore, the comet assay can be used for detection of large-scale changes in the cell nucleus that follow changes in cell functional state.
\end{abstract}

Key words: DNA loop domains, lymphocytes, blast transformation, comet assay, interleukin 2.

$\mathrm{E}$ xperimental evidences in favor of DNA looping as one of the main features of spatial organization of chromatin in cell nucleus have been obtained back to the 1970's [1]. Nevertheless, despite of many experimental approaches being developed, a comprehensive understanding of principles of the loop domain organization was absent for a long time. Development of high-throughput techniques which allow detecting the frequency of interactions between any two distant genomic loci (chromosome conformation capture and related methods) has become a breakthrough in this field $[2,3]$. In-depth analysis of the inter- and intrachromosomal contacts along with proteins that stabilize them revealed that CCCTC-binding factor (CTCF) and cohesin complex play an important role in the loop ends joining [3, 4]. Moreover, these proteins not only act as loop domain holders but they are probably involved in an active process of chromatin loop appearance, so-called "loop extrusion" [4].

Enhancer-promoter pairs often occur at the ends of the loops and thus the loop formation plays an important role in gene regulation: depending on the cell transcriptional profile some loops may arise de novo or disappear [3]. Respectively, the contacts between gene regulatory elements will be established or disrupted [3, 5-7]. Thus, gene transcription should be essentially modulated by (or at least correlated with) changes in spatial organization of chromatin in the cell nucleus.

This article is focused on some features of the loop domain organization in the cells of two types: transcriptionally inert human lymphocytes and transcriptionally active lymphoblasts. To investigate this issue we have applied single cell gel electrophoresis (the comet assay) under neutral conditions. The method is based on electrophoresis of whole cells after depletion of membranes and the vast majority of proteins (so-called lysed cells or nucleoids) [8, 9]. In the case of lysis of intact undamaged cells the nucleoids contain nothing but negatively supercoiled DNA loops attached to some residual protein structures that appear to be insensitive to lysis conditions. During electrophoresis these loops are extended toward the anode to form an electrophoretic track (the comet tail) [10].

In our previous works, which has been done with intact human lymphocytes, we have shown that the comet assay may be successfully applied to study the DNA looping [10, 11]. Using the kinetic approach 
to analyze the extension of the DNA loops under electric force we have estimated several parameters of the comet tails: relative amount of the loops in the tail and their size at different steps of electrophoresis [11]. Moreover, we have measured the supercoiling level in the loops and demonstrated that the rate of the loop migration depends on their supercoiling modulated by intercalating agents [11, 12]. We have also concluded that all the loops in the comet tail may be divided into two subsets: those that origin from the inner volume and surface of nucleoids [11].

Here we address the question about a relationship between cell activation and loop domain organization as it can be seen in the comet assay. The activation of lymphocytes was achieved due to their transformation with interleukin 2 [13-15]. We have found that some redistribution of the loops occurred when lymphocytes were transformed. This rearrangement was related to a change in the ratio between the two subsets of the loops but not to the size of the loops in the comet tails. Our results show that the comet assay may be applied for detection of changes in chromatin three-dimensional organization associated with different functional states of the cell.

\section{Materials and Methods}

Lymphocytes isolation and blast transformation. Human lymphocytes were obtained from peripheral blood of healthy donors by centrifugation in a density gradient (Histopaque 1077, Sigma, USA) according to instructions of the manufacturer. Isolated cells were washed in $0.15 \mathrm{M} \mathrm{NaCl}$ twice and then were put in culture medium: RPMI 1640 medium, supplemented by antibiotics and 10\% fetal bovine serum (Gibco, USA). Recombinant interleukin 2 (1000 units/ml, Biotech-pharm, Russia) was added to the cell culture to induce activation and proliferation of lymphocytes. This cytokine concentration was found to be the most efficient for blast transformation. The cells were then cultivated at $37^{\circ} \mathrm{C}$ for $24 \mathrm{~h}$.

Upon cultivation completion the cells were harvested by centrifugation, washed in Hanks' salt solution and an aliquot of suspension was used for cytological estimation of blast transformation efficiency. For this purpose the cells were incubated in a hypotonic solution $(0.075 \mathrm{M} \mathrm{KCl})$ at $37{ }^{\circ} \mathrm{C}$ for 30 min and then in ethanol : glacial acetic acid $(3: 1)$ fixative solution at $-20{ }^{\circ} \mathrm{C}$ for $10 \mathrm{~min}$. The cell suspension in the fixative in the amount of $0.5 \mathrm{ml}$ was pipetted on microscope slides and dyed with $2 \%$
Giemsa stain. Slides were analyzed with an optical microscope to evaluate a fraction of lymphoblasts per 1000 randomly chosen cells. In our experiments the cultures with the effectiveness of blast transformation no lower than $70 \%$ were used. For several samples of the cultivated cells a flow cytometry cell cycle analysis was also performed.

Sample preparation. A sample of $50 \mu \mathrm{l}$ of the intact or activated (transformed) lymphocytes was embedded in the $0.67 \%$ agarose gel (low-melting point agarose, Sigma, USA) at the surface of a microscope slide, covered with $1 \%$ high-melting point agarose (Chemapol, Czech Republic). After agarose polymerization slides were treated with ice-cold lysis solution $(2.5 \mathrm{M} \mathrm{NaCl}, 100 \mathrm{mM}$ EDTA, $10 \mathrm{mM}$ Tris-HCl (pH 8.0), 1\% Triton X-100 (Ferak, Germany)) for several hours.

Electrophoresis and microscopy. After the lysis slides were washed two times in Hanks' salt solution and electrophoresed $(1 \mathrm{~V} / \mathrm{cm}, 300 \mathrm{~mA})$ in TBE buffer ( $89 \mathrm{mM}$ Tris-borat, 2 мM EDTA, $\mathrm{pH} 7.5$ ) in the dark at $4{ }^{\circ} \mathrm{C}$. Several slides, which were simultaneously prepared in the same way, were placed into the electrophoresis tank, and then they were taken out every 5 or 10 minutes of electrophoresis to study the kinetics of DNA loops migration - we performed the experiment until the parameters measured (see below) stopped to change. Slides were stained with $1.3 \mu \mathrm{g} / \mathrm{ml}$ of DAPI (4',6-diamidino-2-phenylindole, Sigma, USA) and immediately analyzed with a fluorescent microscope (LOMO, Russia) connected with a camera Canon EOS 1000 D. A total 100-200 randomly chosen nucleoids on each slide were examined using image analysis software CometScore (TriTec, USA) to measure the relative amount of DNA in the tails and the tail length. The relative amount of DNA in the tail was determined as the ratio of the tail fluorescence intensity to the total intensity of the comet. The tail length was defined as the distance from the center of mass of the comet head to distal end of the tail. The tail length was multiplied by two and divided by $0.34 \mathrm{~nm}$ to convert it in the contour length (in base pairs) of the longest loops.

Kinetic plot analysis. Two-step kinetic curves (the relative amount of DNA in the tail $f$ versus electrophoresis time $t$ ) were fitted with equation:

$$
f=A_{1}\left(1-\exp \left(-k_{1} t\right)\right)+\frac{A_{2}}{1+\exp \left(k_{2}\left(t_{0}-t\right)\right)},
$$


where $A_{1}$ and $A_{2}$ are the maximum amplitudes of the two components of kinetic plots, $k_{1}$ and $k_{2}$ are the rate constants, and $t_{0}$ is the transition half-time. To obtain the parameters the equation was fitted to experimental data using a least-square procedure.

\section{Results and Discussion}

In our study, using the comet assay, we attempted to make a comparison between nucleoids obtained after lysis of intact and transformed human lymphocytes. To induce the cell transformation, lymphocytes separated from whole blood were stimulated to proliferation with different concentrations of interleukin 2 (250, 500, 1000 units/ml) for $24 \mathrm{~h}$. The cytokine concentration of 1000 units $/ \mathrm{ml}$ was chosen among others since it appeared to be the most effective to induce cell proliferation: the mitotic index (the number of cells at the metaphase stage respective to the total number of cells), which was estimated according to common cytological techniques [16], was $\sim 0.5 \%$ after $48 \mathrm{~h}$ of cultivation. Additionally, an analysis of cell morphology was performed to estimate the fraction of blastoid cells in 24-hour lymphocyte culture (see Materials and Methods). As it was mentioned above, the level of cell transformation reached up to $70 \%$.

Nucleoid DNA integrity (first of all, the absence of single- or double-strand breaks) is a prerequisite for using the comet assay to investigate the loop domains organization [10]. Subsequent to the activation of lymphocytes by interleukin 2 they progress from $\mathrm{G}_{0}$ to $\mathrm{S}$ phase of the cell cycle [13], and after $24 \mathrm{~h}$ of cultivation some cells may be expected to reach the synthesis stage when DNA strand breaks are accumulated in nuclei. Therefore, we have analyzed the distribution of cells at the cell cycle phases by flow cytometry. The results showed that after $24 \mathrm{~h}$ of cultivation the vast majority of cells exists in $\mathrm{G}_{0} /$ $G_{1}$ phases and only small fraction (less than 5\%) reaches DNA synthesis stage.

Performing the comet assay, we have measured the kinetics of DNA exit from nucleoids obtained after lysis of intact and transformed human lymphocytes. Several representative comet images after electrophoresis of lymphocyte-derived and lymphoblast-derived nucleoids are shown in Fig. 1: the comet appearance was about the same in the two cases. The kinetic plots of the average relative amount of DNA in the tails for nucleoids of the two types resemble each other: both plots have a twostep shape (Fig. 2). However, the first step is slower
The kinetic parameters of the DNA exit from lymphocyte- and lymphoblast-derived nucleoids

\begin{tabular}{c|c|c}
\hline Parameter & Lymphocytes & Lymphoblasts \\
\hline$A_{1}$ & $0.07 \pm 0.01$ & $0.14 \pm 0.01$ \\
$\tau_{1}$ & $7.8 \pm 2.9$ & $12.5 \pm 3.9$ \\
$A_{2}$ & $0.14 \pm 0.01$ & $0.08 \pm 0.01$ \\
$k_{2}$ & $0.22 \pm 0.08$ & $0.13 \pm 0.08$ \\
$t_{0}$ & $42.5 \pm 1.0$ & $63.5 \pm 5.0$ \\
\hline
\end{tabular}

$A_{1}$ and $A_{2}$ are the maximum amplitudes of two components of the kinetic plots; $\tau_{1}$ is the characteristic time (the value that is inversely proportional to the rate constant $\left.k_{1}\right), k_{2}$ is the rate constant of the second step of the kinetics plot and $t_{0}$ is the transition half-time for the second step

in the case of lymphoblast-derived nucleoids: the characteristic time $\tau_{1}$ (the value that is inversely proportional to the rate constant $k_{1}$, Eq.1) is slightly higher in comparison with lymphocyte-derived nucleoids (Table). The maximum relative amount of DNA in the comet tails at the first step (the first plateau of the kinetic curves) is twofold higher for lymphoblasts than for lymphocytes (Fig. 2, Table).

The second step of the kinetic plots is sigmoid for both cell types but it is more rapid and begins earlier for lymphocyte-derived nucleoids. In addition, the relative amount of the loops exiting at the second step is very different for the nucleoids of the two types. Provided that the total maximum amount

Lymphocytes Lymphoblasts
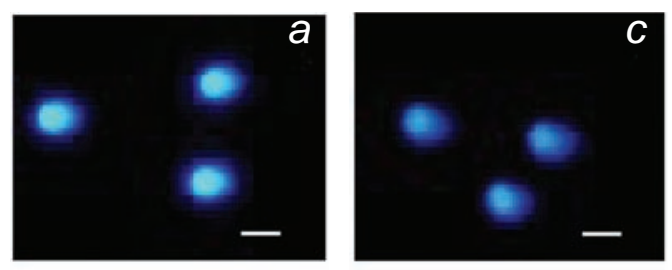

$20 \min$
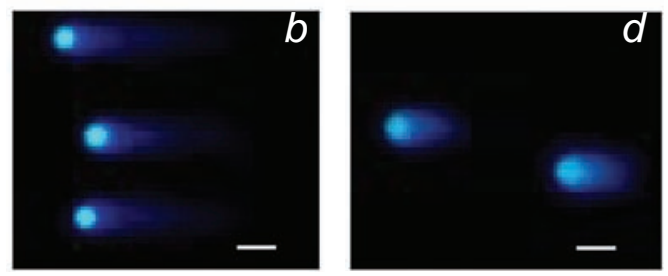

$60 \min$

Fig. 1. The representative comet images of nucleoids obtained after lysis of intact lymphocytes $(a, b)$ and lymphoblasts $(c, d)$ after $20^{\text {th }}$ and $60^{\text {th }}$ minutes of electrophoresis. Bars correspond to $10 \mu \mathrm{m}$ 


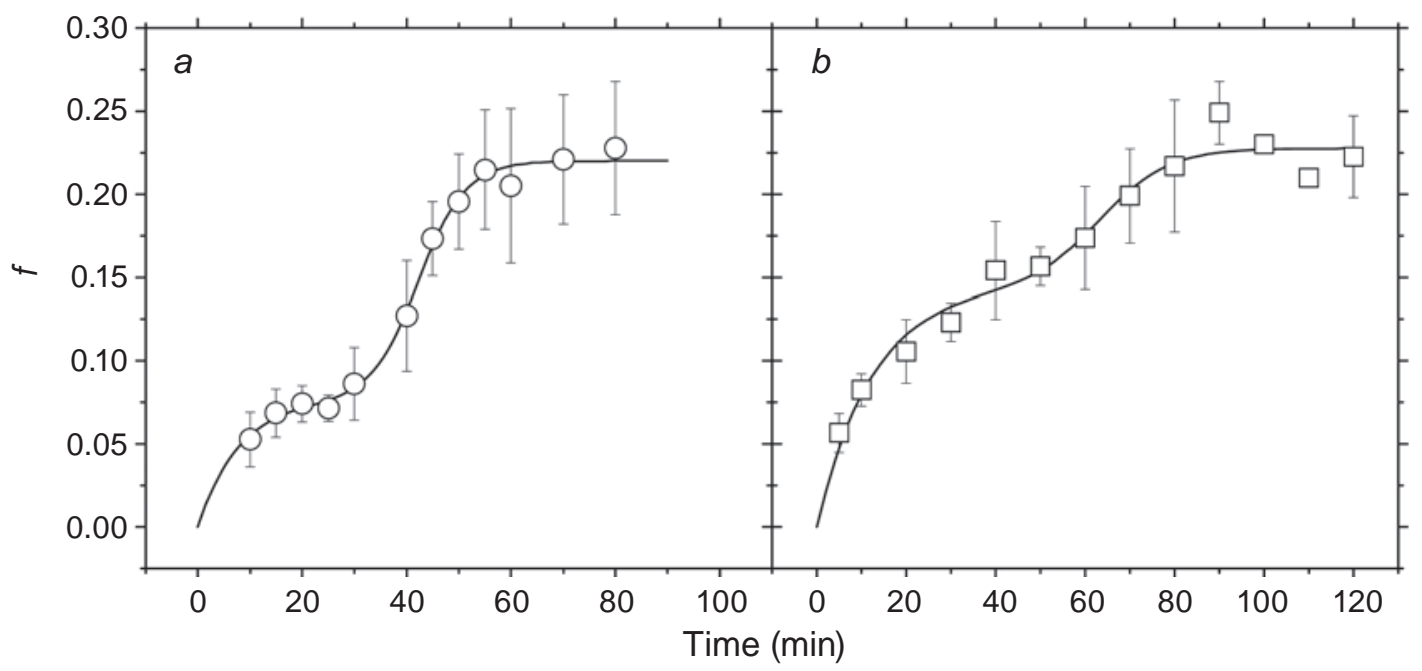

Fig. 2. The average relative amount of DNA in the comet tails $(f)$ as a function of electrophoresis duration for nucleoids prepared from intact (a) and transformed (b) lymphocytes. Here and in next figure, each point is an average for 5 to 10 independent experiments; error bars represent the standard deviations; continuous curves are obtained by fitting as described in Materials and Methods

of DNA in the tails remains the same, the contribution of the second step is about twofold lower for the lymphoblast-derived nucleoids (Fig. 2, Table). Thus, some redistribution of the loop domains in lymphocytes was observed after their transformation.

To explain the differences in the kinetic curves of DNA exit from lymphocyte- and lymphoblastderived nucleoids it is worth to discuss briefly the influence of interleukin 2 on human lymphocytes. It is well-known that highly purified natural or recombinant interleukin 2 is able to induce lymphocyte proliferation via interaction with its receptors at the cell surface [15]. Such interaction activates several signaling pathways that lead to expression of cell cycle-related genes [15, 17]. Changes in transcription patterns during lymphocyte transformation correlate with chromatin reorganization: the size of lymphoblast nuclei (as well as lymphoblastoid cells) increases and euchromatization occurs [18]. As it was mentioned above, gene activation or repression could be directly connected to the loop domain reorganization in the cell nucleus.

Our results show that interleukin 2-stimulated transformation of lymphocytes is associated with an essential increase of the DNA fraction in the comet tails at the first step of electrophoresis (the first plateau on the kinetic plot, Fig. 2, b). In our previous work we have argued that the first step represents the migration of DNA from the nucleoid surface [11]. Therefore, during lymphocyte transformation a growing number of DNA regions are becoming closer to nuclear periphery and thus they are able to migrate rapidly into the comet tail. This assumption is in a good agreement with the nucleus enlargement that is observed during blast transformation.

Despite almost twofold increase in the relative amount of DNA in the comet tails at the first step of electrophoresis after blast transformation, the total amount of DNA that can exit is similar for both cell types. Respectively, the amplitude of the second step $A_{2}$ is equal to $0.14 \pm 0.01$ for lymphocytes while for lymphoblasts this parameter is equal to $0.08 \pm 0.01$. As it was shown in our previous works, the second slow step of the DNA migration reflects an extension of large supercoiled loops that are located inside the nucleus $[10,11]$. On the way towards the anode, these inner supercoiled loops have to overcome, except agarose gel resistance, the resistance made by DNA inside nucleoid and their own torsional constraint that appears in the loops when they are stretched during electrophoresis [10, 11]. Evidently, the migration of these loops requires a prolonged action of the external electric force. We may conclude that an essential decrease in the amount of the inner loops accompanied by a respective increase of the surface loops occurs during lymphocyte transformation.

It should be mentioned that in our experiments the part of DNA, which was found to be able to migrate in the comet tails in lymphocytes and lymphoblasts, is rather small (less than a quarter of the total 


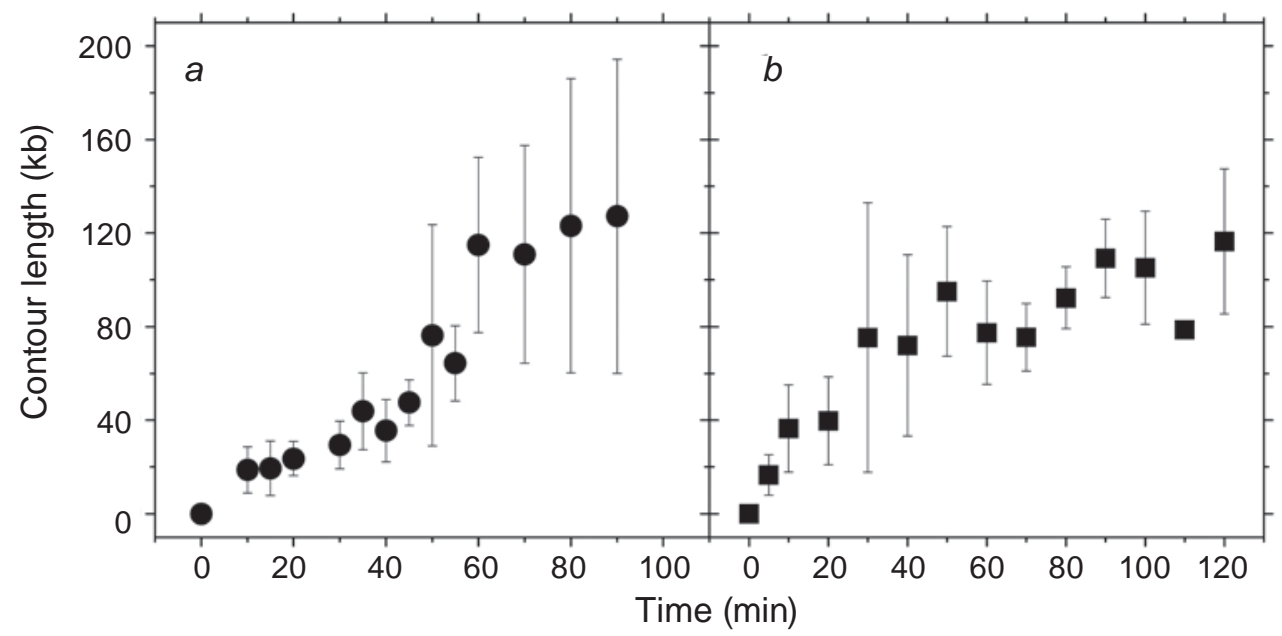

Fig. 3. The average contour length of the longest loops in the tails as a function of electrophoresis duration for lymphocyte-derived nucleoids (a) and lymphoblasts-derived nucleoids (b)

DNA amount in the nucleoid). The simplest explanation of this observation is that most of the loops are too large so that they cannot migrate at all. In other words, the number of loops that may exit during electrophoresis is small and remains the same after lymphocyte transformation.

Applying high-resolution in situ Hi-C technique Rao et al. have identified about 10 thousand loops ranged in size from $40 \mathrm{~kb}$ to $3 \mathrm{Mb}$ with median length $185 \mathrm{~kb}$ [3]. In our experiments the maximum loop size in the comet tails was similar for lymphocyte- and lymphoblast-derived nucleoids: it did not exceed $\sim 127$ and $\sim 116 \mathrm{~kb}$, respectively. However, the average contour length of the loops that migrate into the comet tail at the first step of electrophoresis (first plateau of the kinetic curve) was slightly higher for lymphoblast-derived nucleoids (Fig. 3).

Taken together, our results of the comparative study of the kinetics of DNA exit during electrophoresis of intact and transformed lymphocytes imply that a redistribution of the loop domains occurs after blast transformation. In lymphoblast cells the fraction of loops that are located at nucleus surface is higher in comparison with intact lymphocytes while the number of large inner domains is lower. At the same time, the fraction of loops with contour length that is significantly higher than $100 \mathrm{~kb}$ remains the same for both cell types and did not exceed $25 \%$ of total genome DNA. Our findings allow us to consider the comet assay as a tool to investigate spatial chromatin organization and its alterations in cell nuclei at different stages of cell cycle and in cells with different transcriptional activity.

\section{ПЕРЕРОЗПОДІЛ ПЕТЕЛЬНИХ ДОМЕНІВ ДНК У ЛІМФОЦИТАХ ЛЮДИНИ У РАЗІ БЛАСТТРАНСФОРМАЦІї ЗА ВПЛИВУ ІНТЕРЛЕЙКІНУ 2}

\author{
К. С. Афанасьєва, М. I. Чопей, \\ О. В. Лозовик, С. Р. Рушковський, \\ А. В. Сиволоб
}

\section{ННЦ «Інститут біології та медицини», Київський національний університет імені Тараса Шевченка, Україна; e-mail: aphon@ukr.net}

На вищих рівнях організації в інтерфазному ядрі хроматинові фібрили формують петельні домени. В основі петель часто знаходяться регуляторні ділянки генів - промотори і енхансери. Внаслідок цього петельні домени відіграють важливу роль у регуляції транскрипційної активності клітини. Досліджено кінетику виходу петель ДНК за кометного електрофорезу нуклеоїдів, одержаних із клітин двох типів, які відрізняються за своєю синтетичною активністю - лімфоцитів та лімфобластів людини. Активація лімфоцитів із перетворенням їх у лімфобласти (бласттрансформація) досягалася за допомогою інтерлейкіну 2. Одержані результати свідчать про перерозподіл петель у нуклеоїдах за активації (трансформації) лімфоцита. Після бласттрансформації на поверхні нуклеоїда спостерігалося збільшення кількості петель, що знаходяться на поверхні нуклеоїда, на фоні 
зниження частки внутрішніх петель. Таким чином, кометний електрофорез може бути використаний для реєстрації масштабних змін у клітинному ядрі, що супроводжують зміни функціонального статусу клітин.

К л ю ч о в і с л о в а: петельні домени ДНК, лімфоцити, бласттрансформація, кометний електрофорез, інтерлейкін 2.

\section{ПЕРЕРАСПРЕДЕЛЕНИЕ ПЕТЕЛЬНЫХ ДОМЕНОВ ДНК В ЛИМФОЦИТАХ ЧЕЛОВЕКА ПРИ БЛАСТТРАНСФОРМАЦИИ ПОД ВЛИЯНИЕМ ИНТЕРЛЕЙКИНА 2}

\section{К. С. Афанасьева, М. И. Чопей, \\ А. В. Лозовик, С. Р. Рушковский, \\ А. В. Сиволоб}

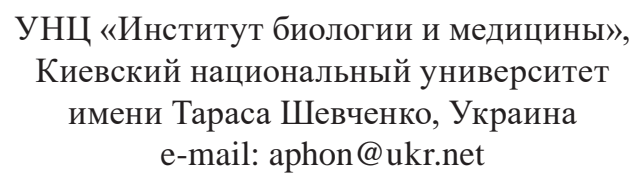

На высших уровнях организации в интерфазном ядре хроматиновые фибриллы формируют петельные домены. В основании петель часто находятся регуляторные участки генов промоторы и энхансеры. По этой причине петельные домены играют важную роль в регуляции транскрипционной активности клетки. Исследована кинетика выхода петель ДНК при кометном электрофорезе нуклеоидов, полученных из клеток двух типов, различающихся своей синтетической активностью, - лимфоцитов и лимфобластов человека. Активация лимфоцитов с преобразованием их в лимфобласты (бласттрансформация) достигалась при помощи интерлейкина 2. Полученные результаты свидетельствуют о перераспределении петель в нуклеоидах при активации (трансформации) лимфоцита. После бласттрансформации наблюдалось увеличение количества петель, находящихся на поверхности нуклеоида, на фоне снижения доли внутренних петель. Таким образом, кометный электрофорез может быть использован для регистрации масштабных изменений в клеточном ядре, сопровождающих изменения функционального статуса клеток.

К л ю че вы е с ло в а: петельные домены ДНК, лимфоциты, бласттрансформация, кометный электрофорез, интерлейкин 2.

\section{References}

1. Cook PR, Brazell IA, Jost E. Characterization of nuclear structures containing superhelical DNA. J Cell Sci. 1976; 22(2): 303-324.

2. Dekker J, Marti-Renom MA, Mirny LA. Exploring the three-dimensional organization of genomes: interpreting chromatin interaction data. Nat Rev Genet. 2013; 14(6): 390-403.

3. Rao SS, Huntley MH, Durand NC, Stamenova EK, Bochkov ID, Robinson JT, Sanborn AL, Machol I, Omer AD, Lander ES, Aiden EL. A 3D map of the human genome at kilobase resolution reveals principles of chromatin looping. Cell. 2014; 159(7): 1665-1680.

4. Sanborn AL, Rao SS, Huang SC, Durand NC, Huntley MH, Jewett AI, Bochkov ID, Chinnappan D, Cutkosky A, Li J, Geeting KP, Gnirke A, Melnikov A, McKenna D, Stamenova EK, Lander ES, Aiden EL. Chromatin extrusion explains key features of loop and domain formation in wild-type and engineered genomes. Proc Natl Acad Sci USA. 2015; 112(47): E6456-E6465.

5. Kadauke S, Blobel GA. Chromatin loops in gene regulation. Biochim Biophys Acta. 2009; 1789(1): 17-25.

6. Cook PR. A model for all genomes: the role of transcription factories. J Mol Biol. 2010; 395(1): 1-10.

7. Tang Z, Luo OJ, Li X, Zheng M, Zhu JJ, Szalaj P, Trzaskoma P, Magalska A, Wlodarczyk J, Ruszczycki B, Michalski P, Piecuch E, Wang P, Wang D, Tian SZ, PenradMobayed M, Sachs LM, Ruan X, Wei CL, Liu ET, Wilczynski GM, Plewczynski D, Li G, Ruan Y. CTCF-Mediated Human 3D Genome Architecture Reveals Chromatin Topology for Transcription. Cell. 2015; 163(7): 1611-1627.

8. 30 years of the comet assay: an overview with some new insights (Azqueta A, Langie S, Collins A., eds.). Lausanne: Frontiers Media, 2015. $174 \mathrm{p}$.

9. Collins AR, Oscoz AA, Brunborg G, Gaivão I, Giovannelli L, Kruszewski M, Smith CC, Stetina R. The comet assay: topical issues. Mutagenesis. 2008; 23(3): 143-151.

10. Afanasieva K, Zazhytska M, Sivolob A. Kinetics of comet formation in single-cell gel electrophoresis: loops and fragments. Electrophoresis. 2010; 31(3): 512-519. 
11. Afanasieva K, Chopei M, Zazhytska M, Vikhreva M, Sivolob A. DNA loop domain organization as revealed by single-cell gel electrophoresis. Biochim Biophys Acta. 2013; 1833(12): 3237-3244.

12. Zazhytska MO, Afanasieva KS, Chopei MI, Vikhreva MA, Sivolob AV. Influence of chloroquine on kinetics of single-cell gel electrophoresis. Biopolym Cell. 2012; 28(4): 292297.

13. Mookerjee BK, Pauly JL. Mitogenic effect of interleukin-2 on unstimulated human $\mathrm{T}$ cells: an editorial review. J Clin Lab Anal. 1990; 4(2): 138-149.

14. Kaplan O, Aebersold P, Cohen JS. Metabolism of peripheral lymphocytes, interleukin-2-activated lymphocytes and tumor-infiltrating lymphocytes from 31P NMR studies. FEBS Lett. 1989; 258(1): 55-58.
15. Bachmann MF, Oxenius A. Interleukin 2: from immunostimulation to immunoregulation and back again. EMBO Rep. 2007; 8(12): 1142-1148.

16. Watt JL, Stephen GS. Lymphocyte culture for chromosome analysis. In: DE Rooney and BH Czepulkowski (Eds.), Human Cytogenetics. A practical approach. IRL Press, Oxford, 1986, P. 39-55.

17. Mzali R, Seguin L, Liot C, Auger A, Pacaud P, Loirand G, Thibault C, Pierre J, Bertoglio J. Regulation of Rho signaling pathways in interleukin-2-stimulated human T-lymphocytes. FASEB J. 2005; 19(13): 1911-1913.

18. Bain BJ. Blood cells: a practical guide. Oxford: Blackwell Publishing, 2006. 476 p.

Received 29.09.2016 